\title{
Unconventional Method of Preparation Intermetallic Phases Fe-Al by Mechanical Alloying in Comparison to Reactive Sintering
}

\author{
Milan Valalik ${ }^{1}$, Pavel Novak ${ }^{1}$, Tomas Frantisek Kubatik ${ }^{2}$, Dalibor Vojtech ${ }^{1}$ \\ ${ }^{1}$ Department of Metals and Corrosion Engineering, University of Chemistry and Technology Prague, Technicka 5, 166 \\ 28, Praha 6, valalikm@gmail.com \\ ${ }^{2}$ Institute of Plasma Physics AS CR, v.v.i. Za Slovankou 1782/3 18200 Prague 8
}

\begin{abstract}
Intermetallic phases $\mathrm{Fe}-\mathrm{Al}$ appears to be a suitable material for industrial use at high temperatures. Due to their characteristic properties, such as high melting point, low toughness at room temperatures and inconvenient casting properties, it is required to explore the other possibilities for their production, especially the technology of powder metallurgy. Recently, the possibility of the preparation of these materials from powder iron and aluminium by reactive sintering technology was studied. Another way of preparation seems to be mechanical alloying and subsequent compaction by SPS. The aim of this study was to describe the mechanism of Fe-Al intermetallic phases during mechanical alloying and optimization of the process parameters. The results of this research were compared with the results of the previous description of the reactive sintering in this system.
\end{abstract}

Keywords: Fe-Al intermetallic phases, mechanical alloying, spark plasma sintering

\section{Acknowledgement}

This research was financially supported by Czech Science Foundation, project No. P108/12/G043.

\section{References}

[1] SAUTHOFF, VON G. (1995). Intermetallics. In: Angewandte Chemie, Vol. 108, Iss. 6, pp. 726-727. VCH Verlagsgesellschaft, Weinheim

[2] LEJCEK, P., NOVAK, P. (2008). Fyzika kovu, pp. 5-28. ICT Prague, Prague.

[3] VOJTECH, D. (2006). Kovove materialy, pp 12-63. ICT Prague, Prague

[4] NOVAK, P., Intermetallic compounds preparation, properties and applications. In: Chemicke listy, Vol. 106, iss.10, pp. 884-889. Prague. Czech republic.

[5] DENKENA, B., STIFFEL, J.-H., HASSELBERG, E., BREIDENSTEIN, B. (2014). Chip formation in monocrystalline iron-aluminum. In: CIRP Journal of Manufacturing Science and Technology, Vol. 7, iss. 2, pp. 71-82.

[6] SURYANARAYANA, C. (2001). Mechanical alloying and milling. In: Elsevier Science Ltd., Vol. 46, iss. 1-2, pp. 1-184.

[7] MURTY, B., RANGANATHAN, S. (1998). Novel materials synthesis by mechanical alloying/milling. In: International Materials Reviews, Vol. 43, No. 3. pp. 101-141.

[8] FOUSOVA, M., CAPEK, J., VOJTECH, D. (2014). Preparation of Magnesium-zinc Alloy by Mechanical Alloying. In: Manufacturing Technology, Vol. 14, No. 3, pp. 304-309.

[9] MUNIR, Z.A., ANSELMI-TAMBURINY,U.,OHYANAGI, M. (2006). The effect of electric field and pressure on synthesis and consolidation of materials: A review of the spark plasma sintering method. In: Journal of Material Science, Vol. 41, iss. 3, pp. 763-777.

[10] ZHIJIAN, S., JOHNSSON, M., ZHAO, Z., NYGREN, M. (2002). Spark Plasma Sintering of alumina. In: Journal of the American Ceramic Society. Vol. 85, iss. 8, pp. 1921-1927.

[11] NOVAK, P., VOJTECH, D., SERAK, J., KUBASEK, J., PRUSA, F., KNOTEK, V., MICHALCOVA, A., NOVAK, M. (2009). Synthesis of Intermediary Phases in Ti-Al-Si System by Reactive Sintering, In: Chemicke listy, Vol. 103, iss. 12, pp. 1022-1026.

[12] NOVAK, P., MICHALCOVA, A.,MAREK, I., VODEROVA, M., VOJTECH, D. (2012). Possibilities of theobservation of chemical reactions during the preparation of intermetallics by reactive sintering. In: Manufacturing Technology, Vol. 12, No.2, pp. 197-201.

[13] MASSALSKI, T.B. (1990). Binary Alloy Phase Diagrams, ASM, Materials Park. 